\title{
Diversity of woody-host infecting Phytophthora species in public parks and botanic gardens as revealed by metabarcoding, and opportunities for mitigation through best practice
}

\author{
Sarah Green', Carolyn E. Riddell², Debbie Frederickson-Matika³, April \\ Armstrong $^{4}$, Matt Elliot ${ }^{5}$, Jack Forster ${ }^{6}$, Pete E. Hedley ${ }^{7}$, Jenny Morris ${ }^{8}$, \\ Peter Thorpe $^{9}$, David E.L. Cooke ${ }^{10}$, Paul M. Sharp ${ }^{11}$ \& Leighton Pritchard ${ }^{12}$
}

\begin{abstract}
The diversity of Phytophthora species in soils collected from 14 highly disturbed sites in northern Britain, including botanic gardens, arboreta, public parks and other amenity woodland sites, was analysed using a molecular technique known as DNA metabarcoding. This technique enables the identification of multiple species present in a single environmental sample based on a DNA 'barcode' unique to each species. The genus Phytophthora was targeted in this study due to its increasing impact on Britain's forests and woodlands over the last 20 years. The introduction and spread of new Phytophthora species into Britain has been strongly associated with the movement of traded containerised plants, with a number of Phytophthora outbreaks reported on host trees located in public gardens and parks that had
\end{abstract}

\footnotetext{
${ }^{1}$ Sarah Green is Forest Pathologist at Forest Research.

Address: Northern Research Station, Roslin, Midlothian, EH25 9SY, UK.

Email: sarah.green@ForestResearch.gov.uk

${ }^{2}$ Carolyn E. Riddell is Forest Pathology Technician and Laboratory Manager at Forest Research.

Address: as above.

${ }^{3}$ Debbie Frederickson-Matika is a Forest Pathology Technician at Forest Research.

Address: as above.

${ }^{4}$ April Armstrong is a Forest Pathology Technician at Forest Research.

Address: as above.

${ }^{5}$ Matt Elliot was Forestry Pathology Technician at Forest Research and is now Conservation Advisor at The Woodland

Trust.

Address: 10 Queensferry Street, Edinburgh, EH2 4PG, UK.

${ }^{6}$ Jack Forster is a Statistician at Forest Research.

Address: Alice Holt Lodge, Farnham, Surrey, GU10 4LS, UK.

${ }^{7}$ Pete E. Hedley is Genome Technology Group Leader at The James Hutton Institute.

Address: Invergowrie, Dundee, DD2 5DA, UK.

${ }^{8}$ Jenny Morris is Sequencing Centre Technician at The James Hutton Institute.

Address: as above.

${ }^{9}$ Peter Thorpe was Postdoctoral Researcher at The James Hutton Institute and is now Bioinformatician at the School of Medicine, University of St Andrews.

Address: North Haugh, St Andrews, KY16 9TF, UK.

${ }^{10}$ David E.L. Cooke is Research Leader and Pathologist at The James Hutton Institute.

Address: Invergowrie, Dundee, DD2 5DA, UK.

${ }^{11}$ Paul M. Sharp is Professor of Genetics at the Institute of Evolutionary Biology, University of Edinburgh.

Address: Charlotte Auerbach Road, Edinburgh, EH9 3FL, UK.

${ }^{12}$ Leighton Pritchard is Computational Biologist at The James Hutton Institute.

Address: Invergowrie, Dundee, DD2 5DA, UK.
} 
recently undergone planting or landscape regeneration schemes. This study was undertaken to assess the extent to which these highly disturbed sites with extensive planting regimes act as harbours for woody-host infecting Phytophthora species. A total of 23 Phytophthora species, the majority of which are known to be pathogens of woody hosts, were detected across the 14 sites sampled. These included four quarantine-regulated pathogens and four species not previously recorded in Britain. Also detected were three as-yet undescribed Phytophthora species and nine oomycete sequences with no clear match to any known genus. There was no effect of geographical location, elevation, underlying soil type, host family or host health status on the Phytophthora assemblages at each site, suggesting that the Phytophthora communities detected are likely to comprise introduced species associated with planting programmes. P. austrocedri and P. pseudosyringae were two of the most abundant Phytophthora species detected, both of which cause serious damage to trees and are regarded as fairly recent introductions to Britain. The practical implications of the findings in terms of mitigating Phytophthora introduction, spread and impact at botanic gardens, arboreta and urban parks are discussed.

\section{Introduction}

Botanic gardens, public parks and arboreta are some of the most highly disturbed wooded sites globally due to their extensive and botanically diverse planting histories and ongoing design schemes. Many of these sites are located in urban areas, receive high visitor numbers and are the focus of international tourism, and so it is perhaps no coincidence that such sites are often the locations of the first documented outbreaks of invasive pests and pathogens of woody hosts (Paap et al., 2017). In Britain, for example, two Phytophthora pathogens (Phytophthora austrocedri and P. lateralis) were first discovered as a result of disease outbreaks on trees located at public parks in close proximity to recent planting schemes (Fig. 1). Other woody-host infecting invasive Phytophthora pathogens, including $P$. ramorum, $P$. kernoviae and $P$. pseudosyringae, have also caused damaging outbreaks in public gardens and arboreta in Britain.

These events are all part of a global pattern of increasing impacts of Phytophthora, partly due to the inadvertent introductions of species into new environments via the plant trade (Brasier, 2008; Jung et al., 2016). Phytophthora is a genus of oomycete plant pathogens which infect a broad range of herbaceous and woody hosts worldwide. Although morphologically fungus-like, Phytophthora species are more closely related to brown algae and produce free-swimming zoospores which are formed in spore sacs known as sporangia (Fig. 2a). Phytophthora species also produce thick-walled resting spores (Fig. 2b) that are able to survive in plant residues and soils for many years. Currently, approximately 180 species of Phytophthora have been described worldwide (Yang et al., 2017) although the true global diversity of this genus of plant pathogens is unknown. Their ability to survive unseen in soil and plant material transported through trade or other pathways means that future invasions of Phytophthora from other global sources are likely to occur.

Given the impact that Phytophthora pathogens are having in the wider environment in Britain and the numerous disease outbreaks at public gardens and arboreta over the last 20 years, we wanted to determine the extent to which such sites 

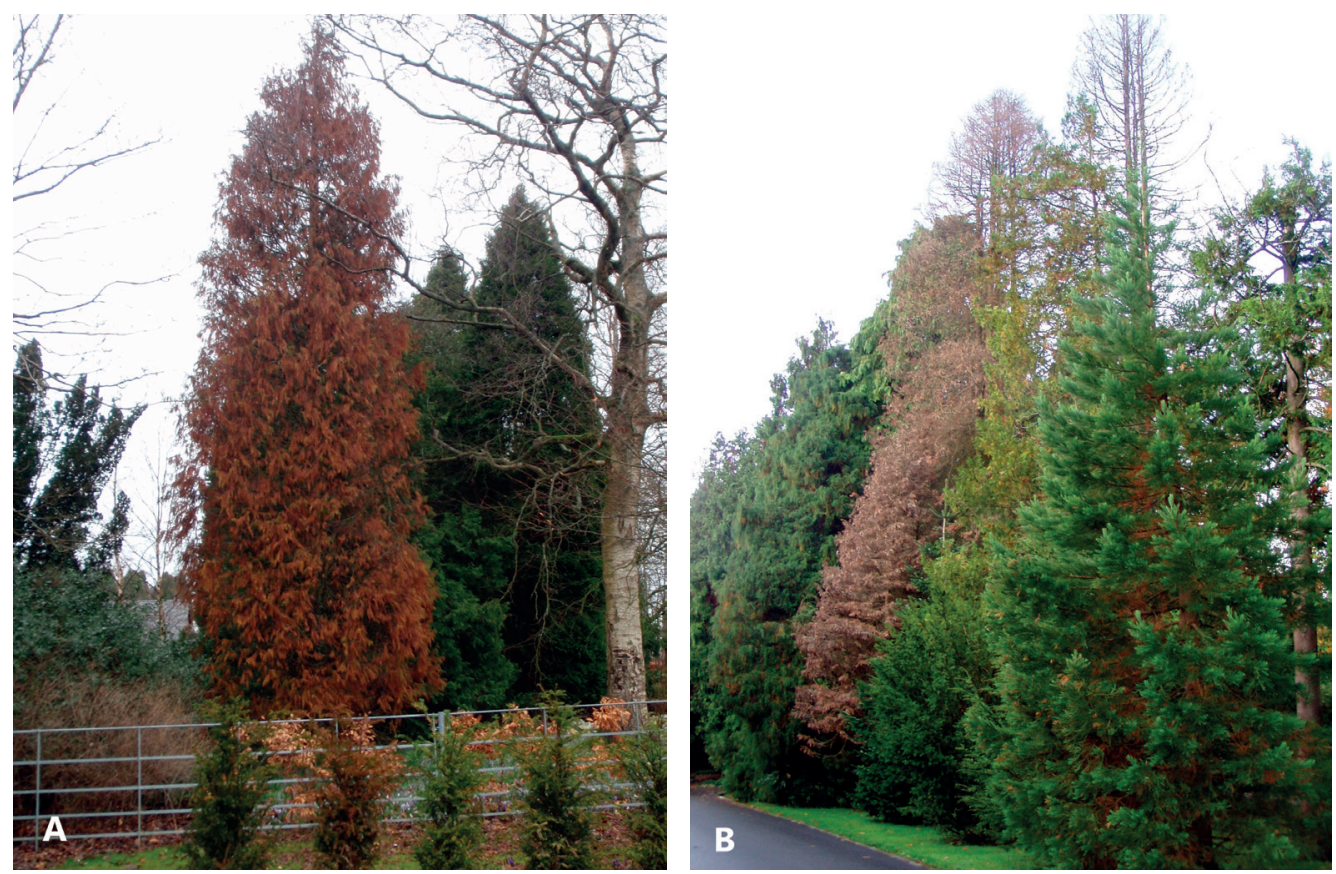

Fig. 1 First reported UK outbreaks of (A) Phytophthora austrocedri on Nootka cypress and (B) P. lateralis on Lawson cypress; in both cases located in public parks and in close proximity to recent planting schemes. Photos: Crown Copyright, Forest Research.
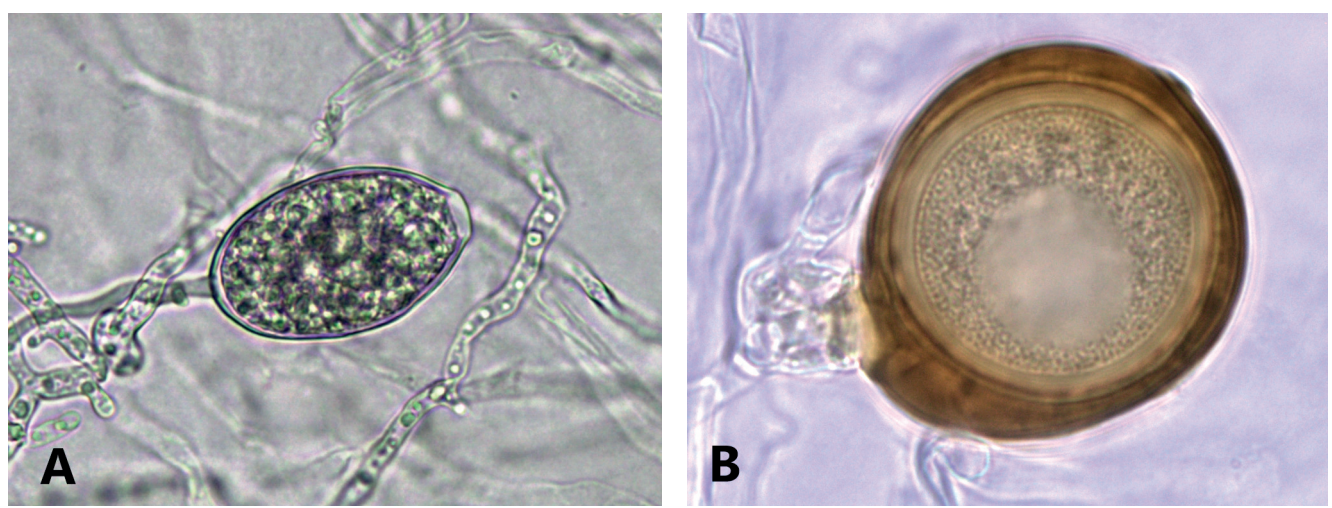

Fig. 2 (A) Phytophthora spore sac known as a sporangium from which the free-swimming zoospores are released. (B) Thick-walled Phytophthora resting spore known as an oospore. Photos: Crown Copyright, Forest Research.

act as reservoirs of woody-host infecting Phytophthora species. To try to capture the highest diversity of Phytophthora species as possible we used a detection tool known as metabarcoding. This is a relatively new method which uses rapidly advancing sequencing technology to detect all species of a target grouping (here, the Phytophthora genus) present within an environmental sample, including species as yet undescribed (Mendoza et al., 2015). Total DNA is extracted from the sample, and a target region of the genome unique to individual species, known as a 'barcode', is amplified and sequenced 
using high-throughput DNA sequencing. Thousands of DNA sequences can be generated from an individual sample, and these are identified by comparing them to a database containing verified sequences from known species. Barsoum et al. (2018) provide an overview of the metabarcoding method and its applications in forestry, including a useful glossary of terms. Previous studies carried out in Italy (Vannini et al., 2013), Spain (Català et al., 2015) and Australia (Burgess et al., 2017) have demonstrated the power of metabarcoding for the analysis of Phytophthora species diversity in soil. Here we review a recent study in which metabarcoding was used to analyse Phytophthora diversity in soils at 14 sites in northern Britain, namely botanic gardens, public parks and other woodland sites with extensive histories of plant importation and/ or documented Phytophthora outbreaks (Riddell et al., 2019). The biological significance and management implications of the species findings are discussed and some practical recommendations for mitigating further Phytophthora impact at these sites are outlined, including the incorporation of a new UK-wide accreditation initiative into plant handing and procurement processes.

\section{Methods}

\section{Soil sampling and processing}

Fourteen sites in northern Britain were sampled between October 2014 and September 2015. These included eleven botanic gardens/public gardens/arboreta, two public cemeteries and one privately owned upland Juniperus communis (juniper) woodland. All except one of the sites had previously confirmed Phytophthora outbreaks and four sites (sites 2, 4, 5 and 14;
Table 1) were located in urban areas. The geographical coordinates and approximate altitude were determined for each site, and for the ten sites not located in urban areas the underlying soil type was determined using the Soil Information for Scottish Soils (SIFSS) web interface. ${ }^{13}$ Soil samples were collected at each site from around ten trees/ shrubs showing visible symptoms typical of Phytophthora infection, such as stem bleeding and/or foliage browning/bronzing, or from around stumps of trees/shrubs felled over the last three to four years due to Phytophthora disease. Outwardly healthy trees/shrubs that are known to be potential Phytophthora hosts were also sampled. The locations of sampling at each site therefore varied according to the above criteria, with sampling points distributed over as wide an area on each site as possible. For each sampling point the geographical coordinates were recorded as well as the genus/species of the tree/shrub present and its condition, either: (1) dead, stump; (2) dead, standing; (3) live but showing symptoms typical of Phytophthora infection; or (4) live, outwardly healthy.

Two soil cores of $2 \mathrm{~cm}$ width $\times 30 \mathrm{~cm}$ depth were collected using a soil auger (Fig. 3) at four points around each individual tree/ shrub/stump within $1 \mathrm{~m}$ horizontal distance from the root collar. The eight soil cores were then pooled and homogenised by hand in a polythene bag to make a single soil sample of approximately 300-400 g per sampling point. Soil samples were frozen within 12 hours of collection before being oven dried at $\sim 60^{\circ} \mathrm{C}$ in aluminium trays for 1-3 days (depending on soil wetness) and stirred thoroughly once dry; the total DNA was then extracted and purified.

${ }^{13}$ Available at http://sifss.hutton.ac.uk 


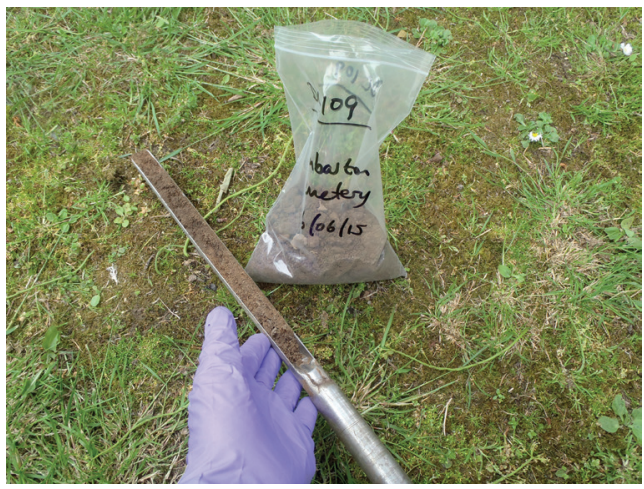

Fig. 3 Soil sample collected using an auger. Photo: Crown Copyright, Forest Research.

\section{Sample preparation for sequencing}

A 'barcode' region of DNA (the ITS1 region) specific to Phytophthora and some closely related oomycete genera was amplified from each soil DNA sample using a PCR (polymerase chain reaction) method developed by Scibetta et al. (2012). Samples were prepared for Illumina high throughput sequencing (Illumina, 2013). Positive control samples containing mixtures of DNA from known Phytophthora species were included in both sequencing runs to check for reliable amplification of the DNA present.

\section{Bioinformatics analysis}

Sequences generated from each soil sample were assigned to clusters based on high DNA sequence similarity using the bioinformatics software 'metapy'.14 Sequence clusters were assigned to species based on a version of the Phytophthora reference database developed by Català et al. (2015) which was updated to include Phytophthora species described since that study. ${ }^{15}$ Any sequences not matching Phytophthora species in the reference database were compared to the annotated collection of all publicly available DNA sequences at GenBank (NCBI), to find the nearest matching species. Computational analyses were conducted to establish whether the novel Phytophthora-like sequences do indeed fall within the Phytophthora taxonomy (Riddell et al., 2019). Statistical analyses of species presence/absence data were carried out using non-metric multidimensional scaling (NMDS), permANOVA and GLiMMs (Riddell et al., 2019).

\section{Baiting to obtain live cultures}

In June 2016 soil samples were additionally collected from around five of the trees/shrubs at Site 12 which had yielded a diverse mix of Phytophthora species in the metabarcoding analysis (Table 1). For each baited sample approximately $250 \mathrm{~g}$ of soil was obtained by pooling four soil cores collected within one horizontal metre of the tree/shrub stem base. For soil baiting, each soil sample was placed in a plastic $500 \mathrm{ml}$ sandwich box filled to twice the depth of the soil with distilled water. Intact leaves of various horticultural and tree species including rhododendron, oak, beech, juniper, hebe, tomato, pepper, petunia and dianthus were placed to float on the water in each sample box (Fig. 4) at room temperature $\left(18-22^{\circ} \mathrm{C}\right)$. Controls were also set up in which each baiting test was replicated in the absence of soil. Bait plants were examined every two days for lesion development, and tissue from the margins of lesions was plated onto agar medium. Any developing colonies were identified as Phytophthora by morphological and molecular analyses. For more details of all methods see Riddell et al. (2019).

\footnotetext{
${ }^{14}$ Available at https://github.com/peterthorpe5/public_scripts/tree/master/metapy (github commit: 6fd1864).

${ }^{15}$ Available at https://github.com/peterthorpe5/public_scripts/blob/master/metapy/data/Riddell_et_al_2019.fasta
} 


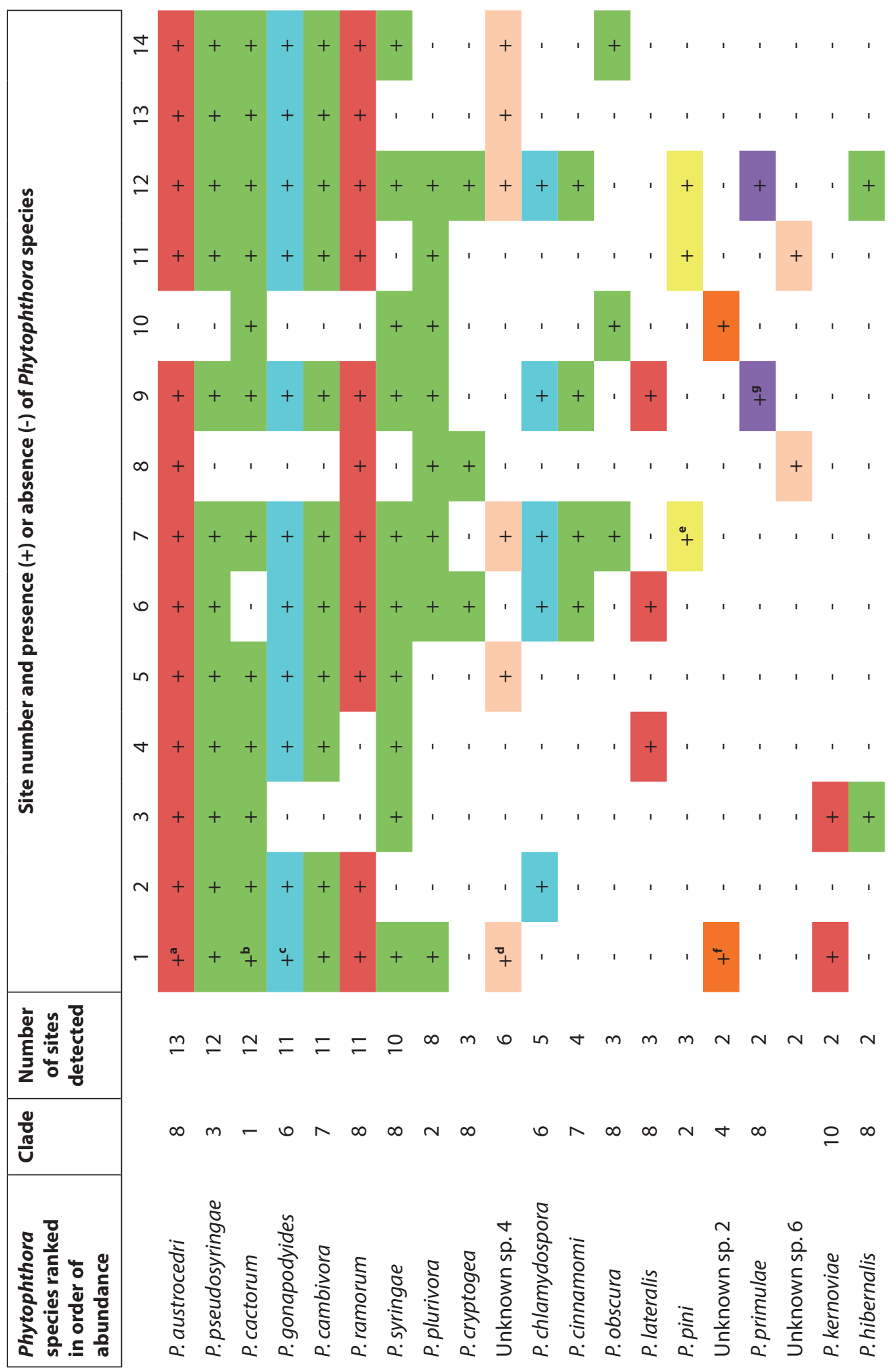




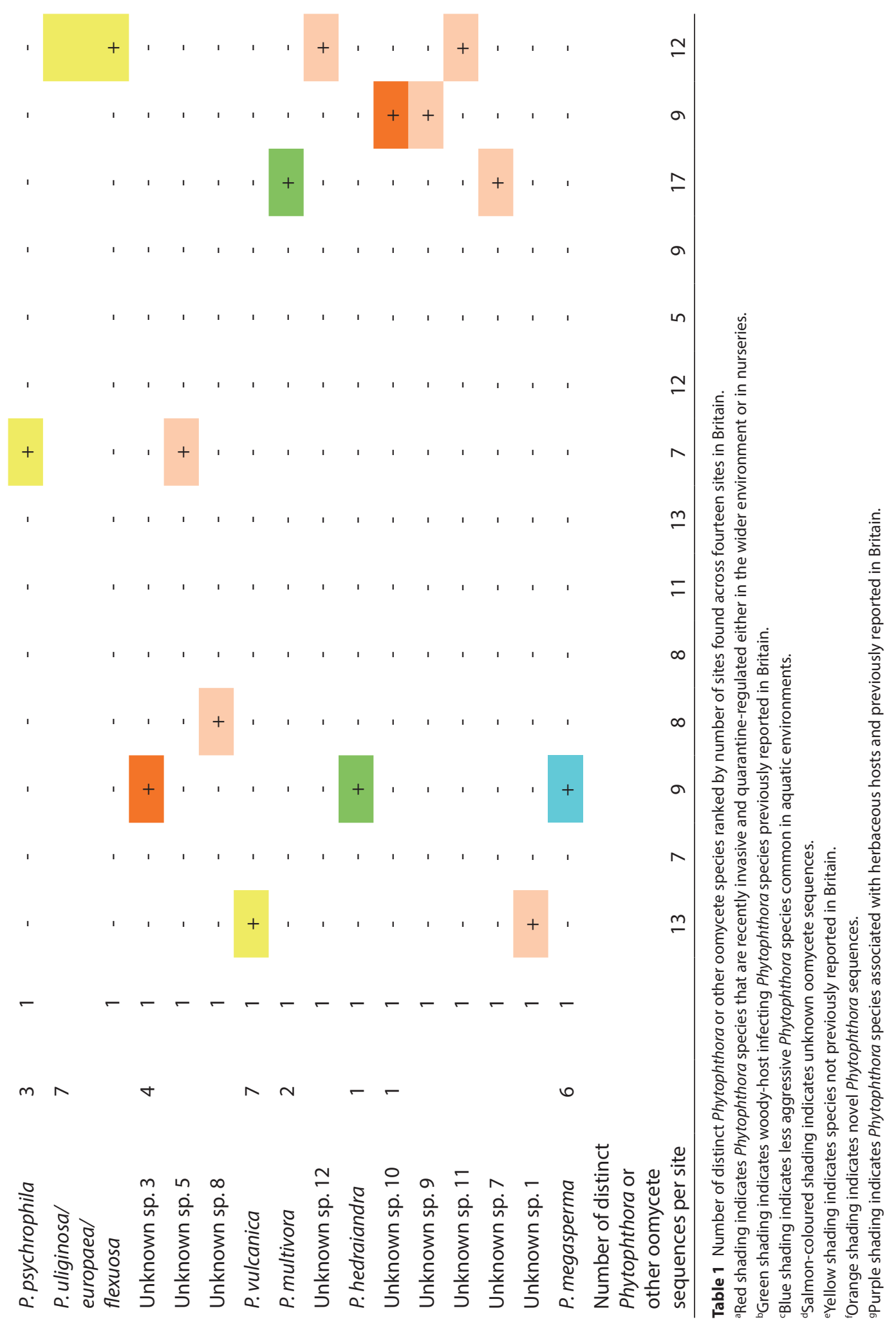




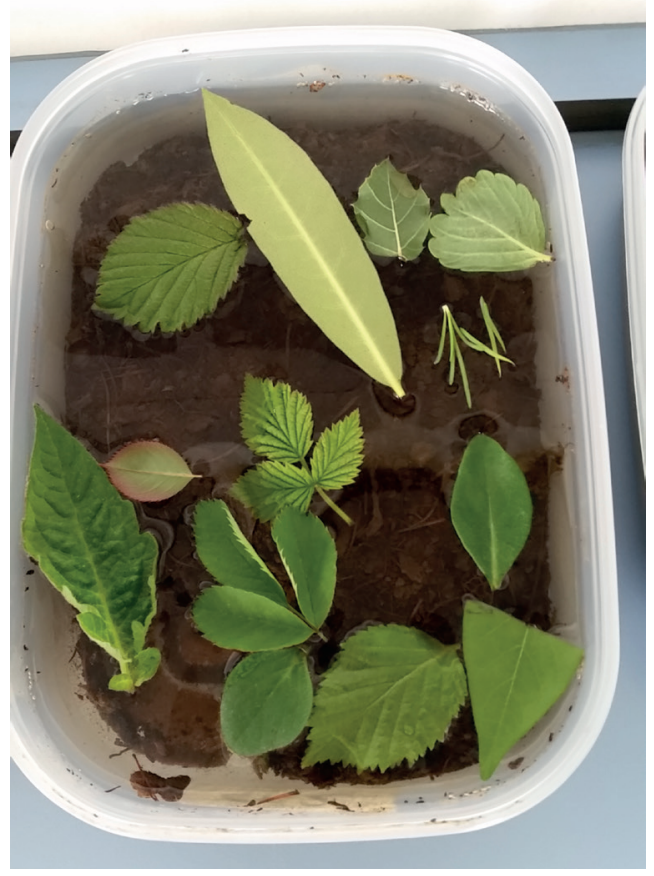

Fig. 4 An illustration of the baiting method used for obtaining living cultures of Phytophthora from soil. Swimming spores are released by Phytophthora species living in the soil when flooded with water. The spores are attracted to the leaves floating on the surface of the water, infecting those which are susceptible. Segments from lesions which develop on the leaves are placed onto a Phytophthora-specific medium and resulting colonies are identified according to colony morphology and DNA analysis. Photo: Crown Copyright, Forest Research.

\section{Results}

Analysis of DNA sequences from soil samples

Of the 140 soil samples collected from the 14 sites, 112 samples and all sites yielded DNA sequences matching Phytophthora, with a total of 23 known Phytophthora species and 3 as-yet undescribed Phytophthora species (i.e. with sequences fitting within the Phytophthora phylogeny but not matching any known species) identified across the study (Table 1). Nine other unknown oomycete sequences were also identified, some of which most closely matched downy mildews (Plasmopara) and Pythium, showing that the metabarcoding tool used in this study can also cross-react with closely related genera. Phytophthora-positive soils were collected from around 34 plant genera of which approximately 25 per cent were outwardly healthy, 40 per cent showed foliage symptoms typical of Phytophthora infection and 35 per cent were either dead or were stumps of hosts with previously confirmed Phytophthora infections. Table 2, in the Appendix, lists the Phytophthora species detected according to host taxonomic criteria. However, statistical analyses found that there was no significant effect of site geographical location, host taxonomic group or host health status on the presence or absence of Phytophthora species (across samples). The only significant factor was the site itself, with site 8 found to have a quite distinct species assemblage compared with other sites; this site differed both in the presence of some species rarely found elsewhere, and in the absence of otherwise common species (Table 1).

Across all sites and samples (Table 1), the most frequently occurring species detected were Phytophthora austrocedri, $P$. pseudosyringae and P. cactorum. Other species detected at the majority of sites were $P$. gonapodyides, $P$. cambivora, $P$. ramorum, $P$. syringae and $P$. plurivora. We identified four quarantine-regulated species (P. ramorum, P. lateralis, P. kernoviae, $P$. austrocedri) and four species not yet reported in the UK (P. psychrophila, P. pini, $P$. vulcanica and $P$. uliginosa/P. europaea/P. flexuosa). Among the 112 soil samples found to have Phytophthora, the mean number of distinct species detected per sample was $4.4(\mathrm{SD}=2.1)$, with values ranging from one to eleven species per sample. Phytophthora species in eight of ten evolutionary clades recognised by Yang 
et al. (2017) were detected; only clades 5 and 9 were not represented. Clade 8 was the most represented clade in this study with eight species detected including three quarantine-regulated pathogens of woody hosts (P. ramorum, P. austrocedri, P. lateralis). Two of the unknown Phytophthora species were phylogenetically placed in clade 4 and one in clade 1 (Riddell et al., 2019). In both positive control mixes, the metabarcoding method detected all except one of the species, $P$. boehmeriae. Lack of amplification of $P$. boehmeriae was likely due to biases incurred during PCR which can mean that some DNA sequences are not amplified as efficiently as others (Pawluczyk et al., 2015).

\section{Baiting to obtain live cultures}

Live cultures of the following species were isolated from the soil samples collected from one of the sites (site 12, Table 1): Phytophthora austrocedri, P. cinnamomi, P. ramorum, P. cryptogea, P. cambivora and P. multivora. All six species were among the fifteen species identified by metabarcoding after sampling twenty months previously (Table 1).

\section{Discussion}

\section{Main findings}

A high diversity of Phytophthora species was detected across the fourteen sites, including nineteen of the forty-two species recently listed as present in the UK (Cooke, 2015) as well as four species not previously reported in this country. Interestingly, the highest number of Phytophthora species was found at a rural botanic garden with no previously recorded outbreaks of Phytophthora disease. Site geographical location, elevation and underlying soil type had no effect on the Phytophthora species detected; neither did the taxonomic grouping or health status of the host tree/shrub central to each sampling point. Since the majority of soils sampled at these sites had been subject to a high turnover of plants, soil and composts over many years, including understorey plantings of annual or perennial herbaceous species, we suspect that the Phytophthora assemblages of any one sample reflect the type and source of material introduced to each location rather than being directly associated with the host tree/shrub around which samples were taken. Therefore, the Phytophthora communities detected at each of these sites likely comprise introduced species associated with planting programmes. Site 8 had a particularly unusual species assemblage compared with other sites, including the only detection of a sequence matching Phytophthora psychrophila, found around a single, dead Chamaecyparis lawsoniana (Lawson cypress). This Phytophthora species, which has not previously been reported in the UK, was first described from soil in European Quercus (oak) forests (Jung et al., 2002). Its true vigour as a pathogen is not known. Site 8 had in the early 2000s been the subject of an extensive programme of landscaping, involving the large-scale removal of invasive Rhododendron ponticum and replanting with around 65 host plant genera brought in from 30 different nurseries, including 16 nurseries located in continental Europe. The regeneration scheme also introduced over 400 tonnes of soil, bark and compost sourced from various suppliers. Subsequently, in 2010 this site hosted the first confirmed outbreak of $P$. lateralis in the UK, which was found to be killing well over 100 mature Lawson cypress trees simultaneously all across the park grounds. The quarantine-regulated pathogen $P$. ramorum was also isolated from the site at the same time. 
Eight Phytophthora species were detected across the majority of sites, and in soils associated with a very wide range of tree/ shrub genera. All eight species infect woody hosts and, apart from $P$. austrocedri, are known to have broad host ranges. Three of these species, P. austrocedri, P. pseudosyringae and $P$. ramorum, are recently invasive and causing severe damage to commercial forest and natural woodland landscapes in the UK. A recent study carried out in Sweden by Redondo et al. (2018) looked at Phytophthora diversity along a gradient of human interference, ranging from plant nurseries to highly managed forests and woodlands to less-managed natural ecosystems. The authors found similar species to those detected in our study, including P. cactorum, P. cambivora, P. gonapodyides, P. pseudosyringae, $P$. ramorum and $P$. syringae. They concluded that invasive Phytophthora species share a common introduction pathway via outplanting of infected nursery stock in urban environments or other sites of high human interference. Pathogen population reservoirs are established at these locations with the more ecologically well adapted species able to spread onwards into wider environments.

\section{Biological significance and} management implications of the Phytophthora species detected Phytophthora austrocedri, P. pseudosyringae and $P$. cactorum were the three most abundant species detected in this study. $P$. austrocedri is causing widespread damage to juniper in northern Britain (Green et al., 2015) (Fig. 5). A different genetic strain of the pathogen is also causing extensive mortality of Austrocedrus chilensis (Chilean cedar) in Argentina (Vélez et al., 2013; Henricot et al., 2017). All known hosts of $P$. austrocedri reside within the family Cupressaceae, on which it is frequently intercepted in trade. These hosts include Lawson cypress, Cupressus nootkatensis (Nootka cypress; also known as Alaskan yellow cedar) and Cupressus $\mathrm{x}$ leylandii (Leyland cypress) (Green et al., 2016). Nootka cypress, in particular, appears to be highly susceptible to $P$. austrocedri with several mature trees rapidly killed during an outbreak at a public park in the south of Glasgow (Green et al., 2016). However, in the current study many soil samples in which we detected $P$. austrocedri DNA and the two soil samples from which $P$. austrocedri was baited were collected from around tree/shrub species not documented as hosts for the pathogen. This pathogen was also found at ten sites where it was not previously known to occur. Our findings suggest either that $P$. austrocedri is well adapted to survive in soil in the absence of infected host material or that it can live in association with a much broader range of plant species than is currently thought. Crone et al. (2013a,b) demonstrated the persistence of resting structures of $P$. cinnamomi in the roots of asymptomatic non-hosts, and P. lateralis has been detected in roots and soil collected from non-host and asymptomatic herbaceous nursery-grown plants in southern Italy including Petunia, Tagetes, Cyclamen and Punica (Prigigallo et al., 2015). It is therefore quite possible that other Phytophthora species are able to exist asymptomatically on non-hosts, and so healthy-looking planting stock may in fact be contaminated with these pathogens if present in the source area.

Phytophthora pseudosyringae is capable of aerial dispersal and was first reported in Britain in 2009 causing disease on Nothofagus spp. (southern beech) (Scanu et al., 2012) and Vaccinium (bilberry) (Beales et al., 2009). This species has subsequently been isolated from Fagus sylvatica (common beech) (Scanu \& 


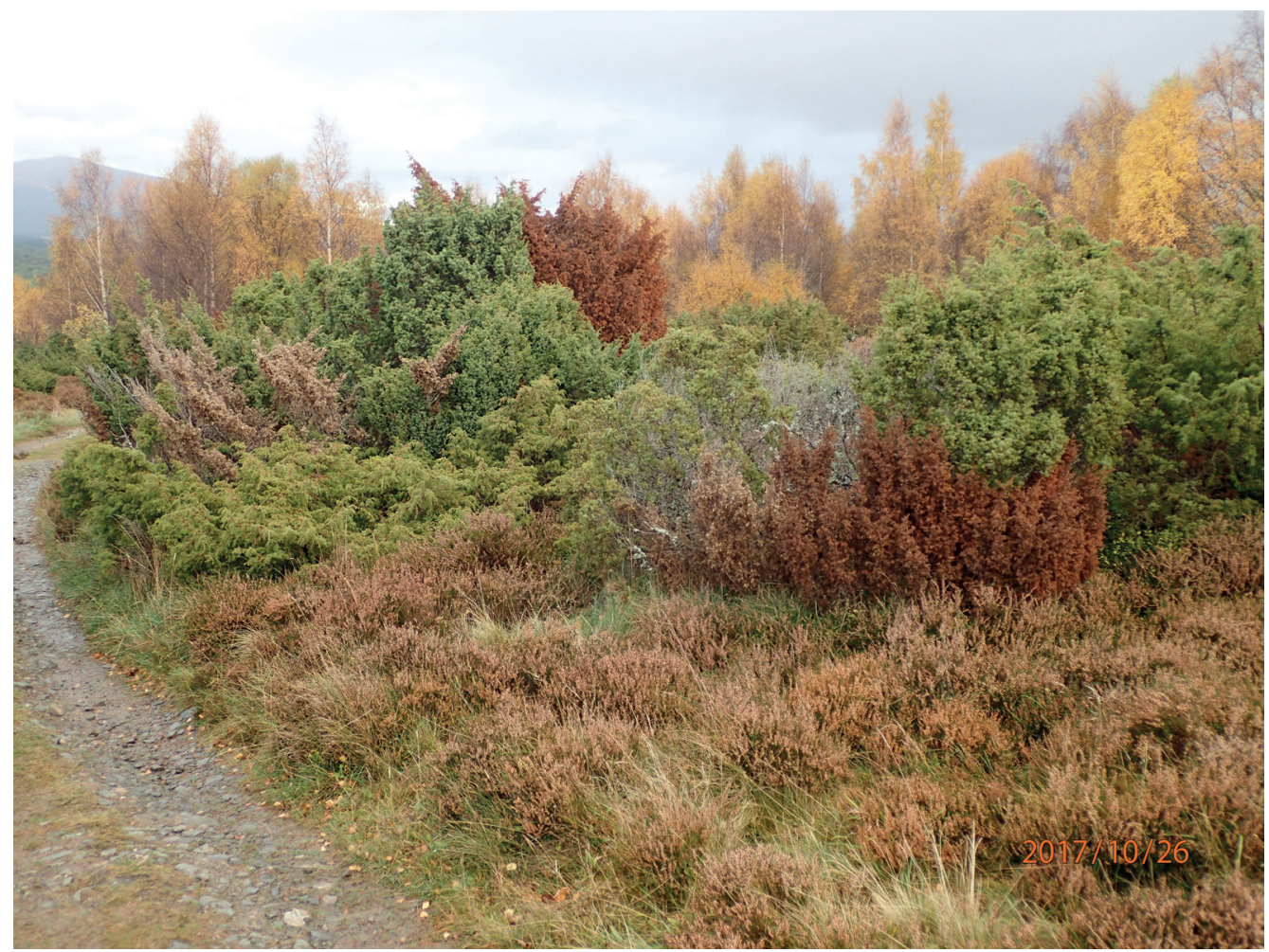

Fig. 5 Juniper in various stages of dieback, from yellowing to characteristic bronzing to complete death, caused by Phytophthora austrocedri. Photo: Crown Copyright, Forest Research.

Webber, 2016) and frequently from aerial stem cankers on Larix kaempferi (Japanese larch) in Britain often together with P. ramorum (J. Webber \& A. Harris, personal communication). More recently, P. pseudosyringae was isolated for the first time from basal cankers on Aesculus hippocastanum (European horse chestnut) in Sweden (Redondo et al., 2016) suggesting that the geographical distribution and potential host range of $P$. pseudosyringae is broader than currently thought. However, the extent to which this pathogen was detected across the sites in this study was surprising given the small number of reported outbreaks in the UK. More studies are needed to establish the host range and relative aggressiveness of $P$. pseudosyringae compared with other species, to better predict its future impact.
Phytophthora cactorum and other abundant Phytophthora species detected in this study, including P. cambivora, P. syringae and $P$. plurivora, are considered common in Britain and cause disease on a wide range of woody and non-woody hosts (Cooke, 2015). Another species detected across a large number of sites was $P$. ramorum, a quarantineregulated pathogen causing extensive mortality of larch species in Britain and with a host range encompassing many shrubby species (Green \& Webber, 2012). Another frequently detected species, $P$. gonapodyides, is commonly found in aquatic habitats (Brasier et al., 2003). This species has been isolated from lesions on diseased trees of various species in Britain (Forest Research Tree Health Diagnostic and Advisory Service, unpublished data) although its role as a pathogen is unclear. 
In this study we also detected DNA matching four Phytophthora species not previously reported in the UK. These included, in addition to P. psychrophila already mentioned above, $P$. pini, $P$. vulcanica and $P$. uliginosa/P. europaea/P. flexuosa. P. pini, detected at three sites, is a well-established pathogen of plants in seven genera including pines and beech as well as ornamentals and vegetables, and it is regarded as an increasing threat to the horticultural industry (Hong et al., 2011). The DNA sequence matching $P$. vulcanica was amplified from soil collected around a single, mature, healthy Castanea sativa (sweet chestnut) at site 1 . This Phytophthora species was described very recently following its isolation from soil collected from beech forests in Sicily and is thought to be a weak pathogen, possibly endemic to Europe (Jung et al., 2017a). The three species, P. uliginosa, P. europaea and $P$. flexuosa, cannot be separated based on the ITS1 locus used in this metabarcoding study. The DNA matching these species was found in soil collected from around a single Betula pendula at site 14. P. flexuosa is only known to occur in Taiwan (Jung et al., 2017b) whereas both $P$. europaea and $P$. uliginosa are known to be present in Europe and associated with oak. Although $P$. europaea is considered to be a weak pathogen, $P$. uliginosa is reported to be much more aggressive (Jung et al., 2002).

Given that many of the Phytophthora species found in this study are likely to have been introduced to each site via planting regimes it will be important to know the extent to which they are present in trade. To this end, the multi-disciplinary project 'Phyto-threats' is investigating the distribution and diversity of Phytophthora species in water and plant samples collected from different plant nursery management systems across Britain. ${ }^{16}$ Understanding species abundance in nurseries and host associations will be key to understanding how these diseases are spread. It is hoped that the project findings will be used to improve best practice and reduce the risk of further introductions and spread of these pathogens.

Interestingly, our metabarcoding method did not readily detect DNA of Phytophthora lateralis, a regulated pathogen of Lawson cypress now considered established in the UK, with many reported outbreaks occurring in parks, gardens and cemeteries in the north-west of the country (Green et al., 2013). This pathogen was detected in far fewer soil samples than expected given that many were collected from around symptomatic Lawson cypress at five P. lateralis outbreak sites. In the Pacific Northwest of the USA, where $P$. lateralis is causing widespread mortality of Lawson cypress in its native range, the pathogen is rarely isolated from soil even in areas of high infestation (Hansen et al., 2000). It can however be baited from the organic fraction of infested soil, suggesting that it persists in soil only on infected root fragments, which were excluded from soil samples in this study.

The DNA detection method used here is only indicative of the presence of a species, and living cultures are needed to confirm the presence and viability of the organism detected and, where new species are concerned, for taxonomic studies and host risk analyses to be undertaken. Baiting returned six of the fifteen Phytophthora species identified

${ }^{16}$ Available at www.forestresearch.gov.uk/research/global-threats-from-phytophthora-spp 
twenty months earlier at the same sampling points by metabarcoding. The discrepancy between the two detection methods is not surprising given the time lag between the two sampling periods and the low sensitivity of baiting which has a tendency to produce false negative results (Vannini et al., 2013). For example, some Phytophthora species are regarded as non-culturable and so the ability to detect them must rely on molecular methods (Català et al., 2017). Baiting also tends to favour fast-growing Phytophthora species or those which have a host preference for the baiting material used and the conditions in which baiting was carried out (Scibetta et al., 2012). Certainly, P. cinnamomi, a warm-temperature pathogen with a very broad host range and responsible for some of the most severe forest disease epidemics worldwide (Crone et al., 2013a,b), dominated the isolates obtained by baiting in this study. P. cryptogea and P. multivora are also fast-growing, cosmopolitan pathogens on many plant species including woody hosts.

\section{Conclusions and implications for management}

This study has demonstrated a high diversity of Phytophthora species pathogenic on woody hosts at the sites sampled in this study. Similar diversity can be expected at other highly disturbed woodland, public garden and amenity sites in Britain. If the DNA detected reflects the presence of live propagules, and the successful baiting of six species at one of the sites suggests that it does, then this also highlights the versatility of this genus of plant pathogens in terms of survival in soil and potential transfer to susceptible hosts. Many of the Phytophthora species found here have previously been recorded in plant nurseries across Europe (Jung et al., 2016), and so our findings emphasise the potential risks posed by the spread of Phytophthora-contaminated soil and planting material. One of the most concerning risks arises from the possible introduction of an unknown and highly damaging new species from its geographical origin where, typically, it exists unnoticed having co-evolved with its hosts. Missions to investigate the centres of origin of Phytophthora are being undertaken by research teams, generally targeting regions of high plant biodiversity such as Southeast Asia and Central America (e.g. Wallace, 2015; Jung et al., 2017b). As information is gathered from these surveys, potentially high-risk pathways from source regions can be identified and efforts focused on preventing future interregional spread of these pathogens. As suggested by Paap et al. (2017) and Hulbert et al. (2017), botanic garden and amenity woodland sites in, or close to, urban areas could be used as sentinel plantings and targeted for early detection of invasive pathogens, particularly where citizen science monitoring programmes could be utilised. In response to the ever-increasing risks posed by trade, and accelerated by the presence of the potentially devastating, broad host-range bacterial pathogen Xylella fastidiosa now present on mainland Europe, the UK's Horticultural Trades Association (HTA) in conjunction with industry are developing a Plant Health Assurance Scheme known as 'Plant Healthy' which, it is hoped, will reach across the entire supply chain. ${ }^{17}$ With this in mind we outline

${ }^{17}$ See https://planthealthy.org.uk 
together with our conclusions a number of practical recommendations for managers of public parks and gardens below:

\section{Practical recommendations}

- Establish good hygiene practice to avoid transfer of soil-borne Phytophthora species within site, and from one site to another. For example, keep public access to hard-core pathways and ensure staff clean boots, tools and vehicles before moving from one location to another on the site.

- Obtain planting stock from reputable nurseries with a documented disease management plan. These criteria should be stipulated in the procurement process. Strongly consider supporting nurseries which have signed up to a Plant Health Assurance Scheme, such as the HTA's 'Plant Healthy' scheme currently under development.

- Keep vigilant for signs of disease and report any new symptoms as soon as they appear to enable a rapid diagnosis and initiation of control strategies, if necessary.

- Metabarcoding is a powerful tool which could be used as part of a wider surveillance strategy for invasive pathogens in Britain.

\section{Acknowledgements}

This work was supported by Forestry Commission Scotland, the Living With Environmental Change Phase 3 project 'Phyto-Threats' as part of the Tree Health and Plant Biosecurity Initiative and the European Union's Horizon 2020 research and innovation programme POnTE (Pest Organisms Threatening Europe).

\section{References}

BARSOUM, N., A'HARA, S., COTTRELL, J. \& GREEN, S. (2018). Using developments in molecular techniques to improve forest biodiversity monitoring. Forestry Commission Research Note 32, Forestry Commission, Edinburgh.

BEALES, P.A., GILTRAP, P.M., WEBB, K.M. \& OZOLINA, A. (2009). A further threat to UK heathland bilberry (Vaccinium myrtillus) by Phytophthora pseudosyringae. New Disease Reports, 19: 56.

BRASIER, C.M. (2008). The biosecurity threat to the UK and global environment from international trade in plants. Plant Pathology, 57: 792-808.

BRASIER, C.M., COOKE, D.E.L., DUNCAN, J.M. \& HANSEN, E.M. (2003). Multiple new phenotypic taxa from trees and riparian ecosystems in Phytophthora gonapodyides- P. megasperma ITS clade 6 , which tend to be high-temperature tolerant and either inbreeding or sterile. Mycological Research, 107: 277-290.

BURGESS, T.I., WHITE, D., MCDOUGALL, K.M., GARNAS, J., DUNSTAN, W.A., CATALÀ, S., CARNEGIE, A.J., WORBOYS, S., CAHILL, D., VETTRAINO, A.-M., STUKELY, M.J.C., LIEW, E.C.Y. ET AL. (2017). Distribution and diversity of Phytophthora across Australia. Pacific Conservation Biology, 23(2): 150-162.

CATALÀ, S., BERBEGA, M., PÉREZ-SIERRA, A. \& ABAD-CAMPOS, P. (2017). Metabarcoding and development of new real-time specific assays reveal Phytophthora species diversity in holm oak forests in eastern Spain. Plant Pathology, 66 115-123.

CATALÀ, S., PÉREZ-SIERRA, A. \& ABAD-CAMPOS, P. (2015). The use of genus-specific amplicon pyrosequencing to assess Phytophthora species diversity using eDNA from soil and water in northern Spain. PLOS ONE, 10, e0119311.

COOKE, D.E.L. (2015). Threats posed by Phytophthora to Scottish plant health; a review of previous findings, pathways of entry and further spread and the status of diagnostic techniques. RESAS Phytophthora Risk Review. Report Commissioned by the Scottish Government. 
CRONE, M., MCCOMB, J.A., O'BRIEN, P.A. \& HARDY, G.E.S. (2013a). Annual and herbaceous perennial native Australian plant species are symptomless hosts of Phytophthora cinnamomi in the Eucalyptus marginata (jarrah) forest of Western Australia. Plant Pathology, 62: 1057-1062.

CRONE, M., MCCOMB, J.A., O'BRIEN, P.A. \& HARDY, G.E.S. (2013b). Survival of Phytophthora cinnamomi as oospores, stromata, and thick-walled chlamydospores in roots of symptomatic and asymptomatic annual and herbaceous perennial plant species. Fungal Biology, 117: 112-123.

GREEN, S., BRASIER, C.M., SCHLENZIG, A., MCCRACKEN, A., MACASKILL, G.A., WILSON, M. \& WEBBER, J.F. (2013). The destructive invasive pathogen Phytophthora lateralis found on Chamaecyparis lawsoniana across the UK. Forest Pathology, 43: 19-28.

GREEN, S., ELLIOT, M., ARMSTRONG, A. \& HENDRY, S.J. (2015). Phytophthora austrocedrae emerges as a serious threat to juniper (Juniperus communis) in Britain. Plant Pathology, 64: 456-466.

GREEN, S., MACASKILL, G.A., DUN, H., ARMSTRONG, A.C. \& HENRICOT, B. (2016). First report of Phytophthora austrocedri infecting Nootka cypress in Britain. New Disease Reports, 33: 21.

GREEN, S. \& WEBBER, J.F. (2012). The emerging threat from Phytophthora to trees in Scotland. Scottish Forestry, 66: 9-16.

HANSEN, E.M., GOHEEN, D.J., JULES, E.S. \& ULLIAN, B. (2000). Managing Port-Orford-Cedar and the introduced pathogen Phytophthora lateralis. Plant Disease, 84: 4-14.

HENRICOT, B., PÉREZ-SIERRA, A., ARMSTRONG, A.C., SHARP, P.M. \& GREEN, S. (2017).

Morphological and genetic analyses of the invasive forest pathogen Phytophthora austrocedri reveal two clonal lineages colonised Britain and Argentina from a common ancestral population. Phytopathology, 107: 1532-1540.

HONG, C., GALLEGLY, M.E., RICHARDSON, P.A. \& KONG, P. (2011). Phytophthora pini Leonian resurrected to distinct species status. Mycologia, 103: 351-360.

HULBERT, J.M., AGNE, M.C., BURGESS, T.I., ROETS, F. \& WINGFIELD, M.J. (2017). Urban environments provide opportunities for early detections of Phytophthora invasions. Biological Invasions, 19: 3629-3644.

ILLUMINA (2013). 16S Metagenomic sequencing library preparation. Available online: http://support.illumina.com/content/dam/ illumina-support/documents/documentation/ chemistry_documentation/16s/16s-metagenomiclibrary-prep-guide-15044223-b.pdf (accessed August 2019).

JUNG, T., HANSEN, E.M., WINTON, L., OBWALD, W. \& DELATOUR, C. (2002). Three new species of Phytophthora from European oak forests. Mycological Research, 106: 397-411.

JUNG, T., JUNG, M.H., CACCIOLA, S.O., CECH, T., BAKONYI, J., SERESS, D., MOSCA, S., SCHENA, L., SEDDAIU, S., PANE, A., MAGNANO DI SAN LIO, A., MAIA, C. ET AL. (2017a). Multiple new cryptic pathogenic Phytophthora species from Fagaceae forests in Austria, Italy and Portugal. IMA Fungus, 8: 219-244.

JUNG, T., JUNG, M.H., SCANU, B., SERESS, D., KOVÁCS, D.M., MAIA, C., PÉREZ-SIERRA, A., CHANG, T.T., CHANDELIER, A., HEUNGENS, K., VAN POUCKE, K., ABAD-CAMPOS, P. ET AL. (2017b). Six new Phytophthora species from ITS Clade 7a including two sexually functional heterothallic hybrid species detected in natural ecosystems in Taiwan. Persoonia, 38: 100-135.

JUNG, T., ORLIKOWSKI, L., HENRICOT, B., ABAD-CAMPOS, P., ADAY, A.G., AGUÍN CASAL, O., BAKONYI, J., CACCIOLA, S.O., CECH, T., CHAVARRIAGA, D., CORCOBADO, T., CRAVADOR, A. ET AL. (2016). Widespread Phytophthora infestations in European nurseries put forest, semi-natural and horticultural ecosystems at high risk of Phytophthora diseases. Forest Pathology, 46: 134-163.

MENDOZA, M.L.Z., SICHERITZ-PONTÉN, T. \& GILBERT, M.T.P. (2015). Environmental genes and genomes: understanding the differences and challenges in the approaches and software for their analyses. Briefings in Bioinformatics, 16: 745-758.

PAAP, T., BURGESS, T.I. \& WINGFIELD, M.J. (2017). Urban trees: bridge-heads for forest pest invasions and sentinels for early detection. Biological Invasions, 19: 3515-3526.

PAWLUCZYK, M., WEISS, J., LINKS, M.G., ARANGUREN, M.E., WILKINSON, M.D. \& 
EGEA-CORTINES, M. (2015). Quantitative evaluation of bias in PCR amplification and next-generation sequencing derived from metabarcoding samples. Analytical and Bioanalytical Chemistry, 407: 1841-1848.

PRIGIGALLO, M.I., MOSCA, S., CACCIOLA, S.O., COOKE, D.E.L. \& SCHENA, L. (2015). Molecular analysis of Phytophthora diversity in nursery-grown ornamental and fruit plants. Plant Pathology, 64: 1308-1319.

REDONDO, M.Á., BOBERG, J., STENLID, J. \& OLIVA, J. (2016). First report of Phytophthora pseudosyringae causing basal cankers on horse chestnut in Sweden. Plant Disease, 100: 1024.

REDONDO, M.Á., BOBERG, J., STENLID, J. \& OLIVA, J. (2018). Functional traits associated with the establishment of introduced Phytophthora spp. in Swedish forests. Journal of Applied Ecology, 55: 1538-1552.

RIDDELL, C.E., FREDERICKSON-MATIKA, D., ARMSTRONG, A.C., ELLIOT, M., FORSTER, J., HEDLEY, P.E., MORRIS, J., THORPE, P., COOKE, D.E.L., PRITCHARD, L., SHARP, P.M. \& GREEN, S. (2019). Metabarcoding reveals a high diversity of woody host-associated Phytophthora spp. in soils at public gardens and amenity woodlands in Britain. PeerJ. doi:10.7717/peerj.6931.

SCANU, B., JONES, B. \& WEBBER, J.F. (2012). A new disease of Nothofagus in Britain caused by
Phytophthora pseudosyringae. New Disease Reports, 25: 27.

SCANU, B. \& WEBBER, J.F. (2016). Dieback and mortality of Nothofagus in Britain: ecology, pathogenicity and sporulation potential of the causal agent Phytophthora pseudosyringae. Plant Pathology, 65: 26-36.

SCIBETTA, S., SCHENA, L., CHIMENTO, A., CACCIOLA, S.O. \& COOKE, D.E.L. (2012). A molecular method to assess Phytophthora diversity in environmental samples. Journal of Microbiological Methods, 88: 356-368.

VANNINI, A., BRUNI, N., TOMASSINI, A., FRANCESCHINI, S. \& VETTRAINO, A.M. (2013). Pyrosequencing of environmental soil samples reveals biodiversity of the Phytophthora resident community in chestnut forests. FEMS Microbiology Ecology, 85: 433-442.

VÉLEZ, M.L., COETZEE, M.P.A., WINGFIELD, M.J., RAJCHENBERG, M. \& GRESLEBIN, A.G. (2013). Evidence of low levels of genetic diversity for the Phytophthora austrocedrae population in Patagonia, Argentina. Plant Pathology, 63: 212-220.

WALLACE, S. (2015). Diversity of Phytophthora species in Costa Rica's tropical forests. MSc thesis, University of Maryland.

YANG, X., TYLER, B.M. \& HONG, C. (2017). An expanded phylogeny for the genus Phytophthora. IMA Fungus, 8: 355-384. 


\section{Appendix}

Table 2 lists the Phytophthora species detected according to host taxonomic criteria.

\begin{tabular}{|c|c|c|}
\hline $\begin{array}{l}\text { Host by family/other } \\
\text { taxonomic category }\end{array}$ & $\begin{array}{l}\text { Host species and number of } \\
\text { individuals sampled across } \\
\text { the study }\end{array}$ & $\begin{array}{l}\text { Phytophthora species detected } \\
\text { in order of overall sequence } \\
\text { abundance }\end{array}$ \\
\hline \multirow[t]{5}{*}{ 1. Cupressaceae } & $\begin{array}{l}\text { Chamaecyparis lawsoniana } \\
26 \text { individuals }\end{array}$ & $\begin{array}{l}\text { P. pseudosyringae } \\
\text { P. austrocedri } \\
\text { P. gonapodyides } \\
\text { P. cambivora } \\
\text { P. cactorum } \\
\text { P. syringae } \\
\text { P. psychrophila } \\
\text { P. ramorum } \\
\text { Unknown sp. } 8 \\
\text { Unknown sp. } 4 \\
\text { P. chlamydospora } \\
\text { P. lateralis } \\
\text { P. plurivora } \\
\text { P. cryptogea }\end{array}$ \\
\hline & $\begin{array}{l}\text { Juniperus spp. } \\
10 \text { individuals }\end{array}$ & $\begin{array}{l}\text { P. pseudosyringae } \\
\text { P. gonapodyides } \\
\text { P. austrocedri } \\
\text { Unknown sp. } 4 \\
\text { P. ramorum } \\
\text { P. cambivora } \\
\text { P. cactorum } \\
\text { Unknown sp. } 10 \\
\text { P. cryptogea } \\
\text { Unknown sp. } 9 \\
\text { P. syringae }\end{array}$ \\
\hline & $\begin{array}{l}\text { Cupressus nootkatensis } \\
3 \text { individuals }\end{array}$ & $\begin{array}{l}\text { P. pseudosyringae } \\
\text { P. austrocedri } \\
\text { P. cactorum } \\
\text { P. gonapodyides } \\
\text { P. cambivora } \\
\text { P. ramorum }\end{array}$ \\
\hline & $\begin{array}{l}\text { Thuja spp. } \\
2 \text { individuals }\end{array}$ & $\begin{array}{l}\text { P. ramorum } \\
\text { P. pseudosyringae } \\
\text { P. cambivora } \\
\text { P. syringae } \\
\text { P. gonapodyides } \\
\text { P. austrocedri } \\
\text { P. cactorum }\end{array}$ \\
\hline & $\begin{array}{l}\text { Metasequoia sp. } \\
1 \text { individual }\end{array}$ & $\begin{array}{l}\text { P. pseudosyringae } \\
\text { P. gonapodyides } \\
\text { P. austrocedri }\end{array}$ \\
\hline
\end{tabular}

Table 2 Phytophthora species detected according to host taxonomic criteria. 


\begin{tabular}{|c|c|c|}
\hline & $\begin{array}{l}\text { Chamaecyparis pisifera } \\
1 \text { individual }\end{array}$ & $\begin{array}{l}\text { P. pseudosyringae } \\
\text { P. gonapodyides } \\
\text { P. austrocedri } \\
\text { P. cambivora } \\
\text { P. cactorum }\end{array}$ \\
\hline & $\begin{array}{l}\text { Taxodium distichum } \\
1 \text { individual }\end{array}$ & $\begin{array}{l}\text { Unknown sp. } 5 \\
\text { Unknown sp. } 6 \\
\text { P. ramorum }\end{array}$ \\
\hline & $\begin{array}{l}\text { Fitzroya } \\
1 \text { individual }\end{array}$ & $\begin{array}{l}\text { P. chlamydospora } \\
\text { P. pseudosyringae } \\
\text { P. ramorum } \\
\text { P. cambivora } \\
\text { P. austrocedri }\end{array}$ \\
\hline & $\begin{array}{l}\text { Xanthocyparis vietnamensis } \\
1 \text { individual }\end{array}$ & $\begin{array}{l}\text { P. austrocedri } \\
\text { P. cinnamomi } \\
\text { Unknown sp. } 4 \\
\text { P. gonapodyides }\end{array}$ \\
\hline & $\begin{array}{l}\text { Leylandii stump } \\
1 \text { individual }\end{array}$ & P. pseudosyringae \\
\hline \multirow[t]{2}{*}{ 2. Ericaceae } & $\begin{array}{l}\text { Rhododendron spp. } \\
19 \text { individuals }\end{array}$ & $\begin{array}{l}\text { P. pseudosyringae } \\
\text { P. cambivora } \\
\text { P. syringae } \\
\text { P. gonapodyides } \\
\text { P. quercina } \\
\text { P. austrocedri } \\
\text { P. plurivora } \\
\text { P. cactorum } \\
\text { P. primulae } \\
\text { Unknown sp. } 3 \\
\text { P. ramorum } \\
\text { P. chlamydospora } \\
\text { P. cinnamomi } \\
\text { P. lateralis } \\
\text { Unknown sp. } 11 \\
\text { P. kernoviae } \\
\text { Unknown sp. } 4 \\
\text { Unknown sp. } 6 \\
\text { P. megasperma } \\
\text { P. hibernalis } \\
\text { P. obscura }\end{array}$ \\
\hline & $\begin{array}{l}\text { Pieris } \\
3 \text { individuals }\end{array}$ & $\begin{array}{l}\text { P. pseudosyringae } \\
\text { P. austrocedri } \\
\text { P. cactorum } \\
\text { P. cambivora } \\
\text { P. multivora } \\
\text { P. syringae } \\
\text { P. gonapodyides }\end{array}$ \\
\hline
\end{tabular}




\begin{tabular}{|c|c|c|}
\hline & $\begin{array}{l}\text { Arbutus sp. } \\
1 \text { individual }\end{array}$ & $\begin{array}{l}\text { P. cinnamomi } \\
\text { P. austrocedri } \\
\text { P. hibernalis }\end{array}$ \\
\hline \multirow[t]{4}{*}{$\begin{array}{l}\text { 3. Fagaceae/ } \\
\text { Nothofagaceae }\end{array}$} & $\begin{array}{l}\text { Quercus spp. } \\
4 \text { individuals }\end{array}$ & $\begin{array}{l}\text { P. austrocedri } \\
\text { P. gonapodyides } \\
\text { P. cambivora } \\
\text { P. pseudosyringae } \\
\text { Unknown sp. } 12 \\
\text { P. plurivora } \\
\text { P. ramorum } \\
\text { P. syringae }\end{array}$ \\
\hline & $\begin{array}{l}\text { Nothofagus sp. } \\
3 \text { individuals }\end{array}$ & $\begin{array}{l}\text { P. pseudosyringae } \\
\text { P. gonapodyides } \\
\text { P. cambivora } \\
\text { P. austrocedri } \\
\text { P. ramorum } \\
\text { P. cactorum } \\
\text { P. chlamydospora } \\
\text { P. obscura }\end{array}$ \\
\hline & $\begin{array}{l}\text { Fagus sylvatica } \\
2 \text { individuals }\end{array}$ & $\begin{array}{l}\text { P. pseudosyringae } \\
\text { P. austrocedri } \\
\text { P. hedraiandra } \\
\text { P. gonapodyides } \\
\text { P. syringae }\end{array}$ \\
\hline & $\begin{array}{l}\text { Castanea sativa } \\
1 \text { individual }\end{array}$ & $\begin{array}{l}\text { P. pseudosyringae } \\
\text { P. vulcanica } \\
\text { P. austrocedri }\end{array}$ \\
\hline \multirow[t]{2}{*}{ 4. Myrtaceae } & $\begin{array}{l}\text { Eucalyptus spp. } \\
2 \text { individuals }\end{array}$ & $\begin{array}{l}\text { P. austrocedri } \\
\text { P. pseudosyringae } \\
\text { P. gonapodyides } \\
\text { P. cambivora } \\
\text { P. ramorum } \\
\text { P. cactorum } \\
\text { P. chlamydospora } \\
\text { P. syringae } \\
\text { P. pini } \\
\text { P. cinnamomi } \\
\text { P. plurivora } \\
\text { P. primulae }\end{array}$ \\
\hline & $\begin{array}{l}\text { Luma sp. } \\
1 \text { individual }\end{array}$ & $\begin{array}{l}\text { P. pseudosyringae } \\
\text { P. austrocedri } \\
\text { P. gonapodyides } \\
\text { P. cambivora } \\
\text { P. ramorum } \\
\text { P. cactorum } \\
\text { P. chlamydospora } \\
\text { P. pini } \\
\text { P. mississippiae } \\
\text { P. cinnamomi } \\
\text { P. syringae }\end{array}$ \\
\hline
\end{tabular}




\begin{tabular}{|c|c|c|}
\hline \multirow[t]{2}{*}{ 5. Pinaceae } & $\begin{array}{l}\text { Larix spp. } \\
2 \text { individuals }\end{array}$ & $\begin{array}{l}\text { P. cambivora } \\
\text { P. chlamydospora } \\
\text { P. syringae } \\
\text { P. pseudosyringae } \\
\text { P. obscura } \\
\text { P. gonapodyides } \\
\text { P. plurivora } \\
\text { P. cryptogea }\end{array}$ \\
\hline & $\begin{array}{l}\text { Pinus sylvestris } \\
1 \text { individual }\end{array}$ & $\begin{array}{l}\text { P. pseudosyringae } \\
\text { P. gonapodyides } \\
\text { P. cambivora } \\
\text { P. chlamydospora } \\
\text { P. syringae } \\
\text { P. cinnamomi } \\
\text { P. cactorum } \\
\text { P. austrocedri }\end{array}$ \\
\hline \multirow[t]{5}{*}{$\begin{array}{l}\text { 6. Other conifers (all in } \\
\text { order Pinales) }\end{array}$} & $\begin{array}{l}\text { Taxus baccata } \\
6 \text { individuals }\end{array}$ & $\begin{array}{l}\text { P. cryptogea } \\
\text { P. pseudosyringae } \\
\text { P. plurivora } \\
\text { P. austrocedri } \\
\text { P. gonapodyides } \\
\text { P. cambivora } \\
\text { P. cactorum } \\
\text { P. ramorum } \\
\text { Unknown sp.1 } \\
\text { P. psychrophila } \\
\text { P. syringae }\end{array}$ \\
\hline & $\begin{array}{l}\text { Araucaria } \\
3 \text { individuals }\end{array}$ & $\begin{array}{l}\text { P. pseudosyringae } \\
\text { P. ramorum } \\
\text { Unknown sp. } 4 \\
\text { P. austrocedri } \\
\text { P. cactorum } \\
\text { P. syringae } \\
\text { P. cambivora } \\
\text { P. gonapodyides } \\
\text { P. plurivora }\end{array}$ \\
\hline & $\begin{array}{l}\text { Taxodium distichum } \\
1 \text { individual }\end{array}$ & $\begin{array}{l}\text { Unknown sp. } 5 \\
\text { Unknown sp. } 6 \\
\text { P. ramorum }\end{array}$ \\
\hline & $\begin{array}{l}\text { Cephalotaxus harringtonii } \\
1 \text { individual }\end{array}$ & $\begin{array}{l}\text { P. pseudosyringae } \\
\text { P. gonapodyides } \\
\text { P. austrocedri }\end{array}$ \\
\hline & $\begin{array}{l}\text { Unknown conifer stump } \\
1 \text { individual }\end{array}$ & $\begin{array}{l}\text { P. pseudosyringae } \\
\text { P. gonapodyides } \\
\text { P. austrocedri }\end{array}$ \\
\hline
\end{tabular}




\begin{tabular}{|c|c|c|}
\hline \multirow[t]{7}{*}{$\begin{array}{l}\text { 7. Other angiosperms } \\
\text { (various orders) }\end{array}$} & $\begin{array}{l}\text { Viburnum spp. } \\
3 \text { individuals }\end{array}$ & $\begin{array}{l}\text { P. austrocedri/P. syringae } \\
\text { P. pseudosyringae } \\
\text { P. chlamydospora } \\
\text { P. cambivora } \\
\text { P. ramorum } \\
\text { P. gonapodyides } \\
\text { P. syringae } \\
\text { P. austrocedri } \\
\text { P. cactorum }\end{array}$ \\
\hline & $\begin{array}{l}\text { Acer sp. } \\
2 \text { individuals }\end{array}$ & $\begin{array}{l}\text { P. pseudosyringae } \\
\text { P. austrocedri } \\
\text { P. gonapodyides } \\
\text { Unknown sp. } 4 \\
\text { P. cambivora } \\
\text { P. cactorum } \\
\text { P. ramorum } \\
\text { P. pini }\end{array}$ \\
\hline & $\begin{array}{l}\text { Magnolia spp. } \\
2 \text { individuals }\end{array}$ & $\begin{array}{l}\text { P. pseudosyringae } \\
\text { P. gonapodyides } \\
\text { P. austrocedri } \\
\text { P. cactorum } \\
\text { P. ramorum } \\
\text { P. plurivora } \\
\text { P. pini } \\
\text { P. syringae }\end{array}$ \\
\hline & $\begin{array}{l}\text { Osmanthus } \\
1 \text { individual }\end{array}$ & $\begin{array}{l}\text { P. pseudosyringae } \\
\text { P. austrocedri } \\
\text { P. cactorum } \\
\text { P. gonapodyides }\end{array}$ \\
\hline & $\begin{array}{l}\text { Betula pendula } \\
1 \text { individual }\end{array}$ & $\begin{array}{l}\text { P. uliginosa/P. europaea/P. flexuosa } \\
\text { P. gonapodyides }\end{array}$ \\
\hline & $\begin{array}{l}\text { Cordyline sp. } \\
1 \text { individual }\end{array}$ & $\begin{array}{l}\text { P. pseudosyringae } \\
\text { P. gonapodyides } \\
\text { P. cambivora } \\
\text { P. austrocedri } \\
\text { P. cactorum } \\
\text { P. ramorum } \\
\text { P. plurivora }\end{array}$ \\
\hline & $\begin{array}{l}\text { Ilex spp. } \\
2 \text { individuals }\end{array}$ & $\begin{array}{l}\text { P. syringae } \\
\text { P. pseudosyringae } \\
\text { P. ramorum } \\
\text { P. obscura } \\
\text { P. cambivora } \\
\text { P. gonapodyides } \\
\text { P. austrocedri } \\
\text { P. kernoviae }\end{array}$ \\
\hline
\end{tabular}




\begin{tabular}{|l|l|l|}
\hline 8. Other & Gingko biloba & P. cambivora \\
& 1 individual & P. austrocedri \\
\cline { 2 - 3 } & Tree fern & P. pseudosyringae \\
& 2 individuals & P. gonapodyides \\
& P. cambivora \\
& P. austrocedri \\
& P. ramorum \\
& P. syringae \\
& P. cinnamomi \\
& Unknown sp. 7 \\
\hline
\end{tabular}

